\title{
Habitat Use by Feral Horses in the Northern Sagebrush
} Steppe

\author{
DAVID GANSKOPP AND MARTIN VAVRA
}

\begin{abstract}
Distribution patterns of feral horses (Equus caballus) relative to plant communities, herbaceous production, and perennial water sources were studied from April 1979 to March 1981 in Oregon's Owyhee Breaks. Repeated observations of radio-collared and easily identified horses allowed estimation of home range sizes and documentation of the plant communities utilized. A map of plant communities was constructed, and composition and herbaceous production of key communities sampled. Time-lapse cameras monitored the daylight watering patterns of horses. One hundred thirty-three horses were initially censused and identified on the study area with the total population subsequently increasing at an annual rate of $13 \%$. Home ranges averaged $12 \mathrm{~km}^{2}$ with the minimum convex polygon procedure and $27 \mathrm{~km}^{2}$ with the $90 \%$ confidence ellipse method. No seasonal shifts in home ranges occurred, and no correlations were detected between home range size and number of horses per band, densities of perennial water sources, or levels of forage production within home ranges. Six distinct herds were identified on the area. Only one band of horses moved from one herd to another during the 2-year study. Animals in each herd made greatest use of the most prevalent plant community, with no community being universally preferred to over another. Watering activities were most intense during the first and last periods of daylight. Horses rapidly vacated the watering areas after drinking. A seasonal trend was observed in which horses remained slightly closer to perennial water sources during warm, dry summer months than during spring periods when additional seasonal sources were available. Seasonal differences were not statistically significant, however.
\end{abstract}

A knowledge of the distribution and movement patterns of large herbivores is especially valuable to managers charged with allocat-

Authors are, respectively, former graduate student, Department of Rangeland Resources, Oregon State University, Corvallis 97331 , and presently range scientist, USDA-ARS, Eastern Oregon Agricultural Research Center, Squaw Butte Station, Burns 97720, and superintendent, Eastern Oregon Agricultural Research Center, Burns 97720 .

This research was a cooperative effort jointly funded by the Bureau of Land Management, contract number YA-512-CT8-137, and the Eastern Oregon Agricultural Research Center.

Technical paper number 7517. Oregon Agricultural Experiment Station.

Manuscript accepted 29 August 1985. ing resources or assessing impacts of large herbivore use. With the passage of Public Law 92-195 in 1971, feral horses (Equus caballus) in the United States became a particularly vexing problem for public land managers. Since 1971 our knowledge of feral horses has increased, but our understanding of their habits is far from complete.

Because of differences in habitat, results and management suggestions from specific studies are of ten inapplicable to other areas. This research was initiated because few data were available describing patterns of resource use by feral horses in the sagebrush (Artemisia spp.)/bunchgrass vegetation of the Pacific Northwest. The objectives of this study were to characterize the population and to document patterns of habitat use by feral horses relative to plan communities, herbaceous production, and permanent water sources in Oregon's Owyhee Breaks.

Estimates of home range sizes of feral horses vary from $0.9 \mathrm{~km}^{2}$ in Nova Scotia to $303 \mathrm{~km}^{2}$ in Wyoming's Red Desert (Welsh 1975, Miller 1983b). Behavioral aspects influencing distribution patterns of feral horses include a highly developed social organization of harem groups or bands, multiple male and female bands, and bachelor groups (Pellegrini 1971, Feist 1971, Zarn et al. 1977, Berger 1977, Nelson 1978, Salter 1978, Miller 1980). We measured the home ranges of several horses during a 2-year study and tested the hypothesis that bands and bachelor males have home ranges of equivalent size. Miller (1983b) proposed that distribution and abundance of required resources may influence home range size. We examined his hypothesis by correlating variations in home range size with herbage production within home ranges, densities of water sources within home ranges, and the number of horses constituting a band.

When various groups of horses have overlapping home ranges they may further combine to form larger groups or "herds"(Miller and Denniston 1979), which Miller (1983b) proposed as the logical management unit for feral horses. Researchers in several areas have noted movements of horses in response to plant phenology and forage availability (Nelson 1978, Salter and Hudson 1979, 
Miller 1983b). With this in mind, we tested the hypothesis that individual herds of horses randomly used the plant communities within their respective herd areas.

Numerous observers have also noted seasonal movements of horses in response to fluctuations in the availability of water (Welsh 1975, Hansen et al. 1977, Storrar et al. 1977, Miller 1983a). Where water supplies are restricted, the continuous occupation of a source by horses may hinder the use of water by other species (Miller 1980). We noted the distance of sightings of horses from water and tested the hypothesis that there were no seasonal fluctuations in the dispersal of horses around permanent water sources. We also monitored the daylight watering activities of horses with time lapse cameras and tested the hypothesis that horses watered at random throughout the day.

\section{Study Area}

The study was conducted approximately $64 \mathrm{~km}$ south of Vale, Oregon, on a $312-\mathrm{km}^{2}$ area bordering the east bank of the Owyhee Reservoir. The area was divided into 3 pastures by fences and natural barriers and was administered by the Bureau of Land Management. Topography ranges from well-eroded, gently rolling hills to mountainous ridges, cliffrock, and canyons. Elevations range from $809 \mathrm{~m}$, pool level of the Owyhee Reservoir, to $1,687 \mathrm{~m}$. Thirty-year average annual precipitation (1941-1970) at the Owyhee Dam is $22.3 \mathrm{~cm}$, with respective record high and low temperatures at the same station being 44 and $-30^{\circ} \mathrm{C}$.

In the early 1880 's a rancher released approximately 300 brood mares in the area (U.S.D.I., Bureau of Land Management, Vale, Oregon, unpublished), and large numbers of horses have been present since that time. The population peaked in the 1940's with an estimated 2,500 horses (Baltazor and Baltazor 1976). Over the years the population was reduced by both rancher and agency sponsored gatherings, and current Bureau of Land Management guidelines specify maintenance of between 90 and 180 horses. The area also supports 1,600 to 3,900 AUM's of spring and summer livestock use as well as a resident population of roughly $100 \mathrm{Cali}-$ fornia bighorn sheep (Ovis canadensis californiana) and a wintering herd of 200 to 300 mule deer (Odocoileus hemionus hemionus).

\section{Methods}

A map of plant communities was constructed with the aid of aerial photos and reconnaissance of the entire area. Five of the 15 communities detected were sampled for botanical composition and herbage production. These 5 communities supported nearly $93 \%$ of the observed use by ungulates in the area.

Peak standing herbaceous production of these communities was sampled with the double sampling, weight estimate method of Pechanec and Pickford (1937) during both years of study and averaged between years. During the initial sampling period, May 1979 , a 25-m transect was established on 2 representative areas of each community and forage was clipped from a $0.5-\mathrm{m}^{2}$ circular plot positioned at $1-\mathrm{m}$ intervals. From these data, sample numbers sufficient to estimate dominant species production within $10 \%$ of the mean $(P \leq 0.10)$ were calculated and employed in subsequent sampling periods (Stein 1945).

Data describing habitat use of undisturbed horses were gathered during continuous field work spanning April 1979 through March 1981. Movement about the area was accomplished with 4-wheeldrive vehicles and foot travel. The entire area was thoroughly surveyed at least once monthly, with the intent of locating as many horses as possible. Incidental sightings of horses were also recorded while we were involved with other aspects of this project. Binoculars and a 20 - to 40 -power spotting scope facilitated long range identification and observation of horses. Initial efforts focused on a total count and identification of all horses on the area. Thereafter, recorded information included identity and numbers of horses as well as their location and the plant communities occupied. Repeated observations of 11 radio-collared and 13 easily identified horses or bands were used to estimate sizes of home ranges. A coordinate grid, superimposed on a map of the area, allowed documentation of sighting locations. Resolution of the grid placed each sighting within a 16-ha area.

Home range was defined as the area traversed by an individual or socially cohesive group in its normal activities of foraging, mating, and caring for young (Burt 1943). Two methods were used to derive indices of home range size. The first involved construction of the smallest convex polygon enclosing all relocations (Southwood 1966). Polygon areas were estimated with the mapmaker's formula (Jennrich and Turner 1969). This method of home range estimation has historical prominence and graphical simplicity, but contains a serious negative bias with small sample sizes (Jennrich and Turner 1969, Schoener 1981).

Ellipse procedures, as described by Jennrich and Turner (1969) and modified by Koeppl et al. (1975), provided the second estimate of home range size. This method involved construction of a $90 \%$ confidence ellipse about relocation coordinates and enabled one to determine a probability of finding an individual or group within a given area (Harrison 1958). Ellipse dimensions are expanded by the $F$ statistic, which provides some compensation for small sample numbers (Koeppl et al. 1975). This procedure assumes data conform to a bivariate normal distribution. Conformation $(\alpha=$ 0.05 ) was tested with a procedure presented by Smith (1983).

Home range ellipses and polygons were then superimposed on a map of the study area. If some portion of either outline extended into areas deemed inaccessible to horses (over cliffs, lake surfaces, or ungated fences), that area was discounted from the original estimate of home range size. The hypothesis that the average home ranges of bands and bachelor males were of equivalent size was examined with Student's $t$ test $(\alpha=0.05)$.

Each polygon and ellipse was also superimposed on the plant community map and the area of each community occurring in its bounds was estimated with the aid of a random dot overlay and counts of dots falling in each community. Weighted averages were employed to estimate mean herbaceous production per hectare for each home range. Mean herbage production per hectare, water source density, and the maximum number of horses per band (independent variables) were regressed against home range area to test the hypothesis that home range size was related to the availability of resources or the number of horses in a social unit.

Chi-square analysis was used to test the null hypothesis $\left(\mathrm{H}_{0}\right)$ that herds of horses utilized plant communities randomly or in proportion to their availability on the area. Because horses segregated into 6 distinct herds, data were compiled and analyzed on a herd basis. Only plant communities within outlined herd areas were considered available for use. Herd areas were outlined with a modified minimum convex polygon method. The modification involved sightings within $400 \mathrm{~m}$ of impassable barriers. In these cases, the barrier was assumed to be the boundary of the herd area. Two of the herds (numbers 3 and 6), containing small numbers of horses, were insufficiently sampled and not included in this analysis. Herd areas were outlined on the plant community map and the areas of plant communities estimated with counts from random dot overlays. When the null hypothesis of proportional use of plant communities was rejected $(P<0.05)$, simultaneous confidence intervals for differences between proportions $(P<0.02)$ were derived to examine the hypothesis that plant communities were used in greater, equal, or lesser proportions than their availability in the herd area (Marcum and Loftsgaarden 1980). Relative preference ratings were derived for each community following procedures of Krueger (1972). Values less than 1 indicate a plant community was utilized at less than expected levels, and values greater than 1 indicate plant communities were utilized at greater than expected levels. When communities are utilized in proportion to their occurrence on the area, a preference rating of 1 is obtained.

Daily watering patterns of horses were monitored in July and August of 1979 with 3 time-lapse cameras. Exposure settings ranged 
from 30 to 90-second intervals. Photocells activated cameras from roughly $1 / 2$ hour before sunrise to $1 / 2$ hour after sunset. Differences in camera orientation and daily fluctuations in cloud cover, however, prevented an accurate estimate of camera start and stop times. Because time of day could not be accurately determined from films, the number of frames exposed each day were counted and the day divided into 12 periods. Periods were roughly 78 minutes in length. An "animal frame" was defined as an exposure containing one or more animals within approximately $15 \mathrm{~m}$ of water and was not weighted by the number of animals present. The duration of a watering "event" was the total number of continuous frames in which the watering area was occupied by one or more animals, multiplied by the elapsed time between successive exposures. Data were assigned to the appropriate period after film for an entire day had been evaluated. Chi-square analysis of homogeneity was used to test the null hypothesis that horses watered randomly throughout the day. When $\mathrm{H}_{0}$ was rejected $(P<0.05)$, simultaneous confidence intervals for differences between proportions $(P<0.02)$ were derived to examine the hypothesis that specific watering periods were used in greater, equal, or lesser proportions than expected (Marcum and Loftsgaarden 1980).

Coordinates for each sighting of horses were also used to estimate distance to the nearest permanent water source in the largest of the 3 pastures. Data were pooled by season (spring, summer, fall, and winter) and analysis of variance was used to test the hypothesis that mean distance of sightings from water were equivalent among seasons $(\alpha=0.05)$.

\section{Results and Discussion}

\section{Plant Communities}

Major plant communities supported shrub overstories dominated by Wyoming big sagebrush (Artemisia tridentata wyomingensis) or low sagebrush (Artemisia arbuscula) (Table 1). Herbaceous layer dominants included bluebunch wheatgrass (Agropyron spicatum), Sandberg's bluegrass (Poa sandbergii), or cheat-

Table 1. Area (h) of plant communities found in each pasture of the Owyhee study area.

\begin{tabular}{|c|c|c|c|}
\hline \multirow[b]{2}{*}{ Plant community } & \multicolumn{3}{|c|}{ Pasture } \\
\hline & $\begin{array}{l}\text { Wild- } \\
\text { horse }\end{array}$ & $\begin{array}{c}\text { Mc- } \\
\text { Intyre }\end{array}$ & $\begin{array}{l}\text { River- } \\
\text { side }\end{array}$ \\
\hline $\begin{array}{l}\text { Wyoming big sagebrush/ } \\
\text { bluebunch wheatgrass }\end{array}$ & 4193 & 31 & 5443 \\
\hline Wyoming big sagebrush/cheatgrass & 762 & 69 & 5272 \\
\hline $\begin{array}{l}\text { Wyoming big sagebrush/Sandberg's } \\
\text { bluegrass }\end{array}$ & 589 & 2046 & 5173 \\
\hline Low sagebrush/bluebunch wheatgrass & & & 1029 \\
\hline Low sagebrush/Sandberg's bluegrass & & 879 & 2288 \\
\hline Bluebunch wheatgrass & & & 120 \\
\hline Cheatgrass & 347 & & 401 \\
\hline Low sagebrush/cheatgrass & & & 17 \\
\hline Shrub scabland & 314 & 22 & 1882 \\
\hline Bitterbrush/grass & & 12 & 55 \\
\hline Stiff sagebrush/Sandberg's bluegrass & & 32 & \\
\hline Mountain mahogany/grass & & & 26 \\
\hline Silver sagebrush & 3 & & \\
\hline Cliffrock & & & 192 \\
\hline Gravel slopes & & & 51 \\
\hline Total & 6208 & 3091 & 21949 \\
\hline
\end{tabular}

grass (Bromus tectorum). Areas supporting bluebunch wheatgrass were generally associated with steep slopes, while cheatgrass and Sandberg's bluegrass were typically dominants on gentle topography or in large basins and major drainages.

Five plant communities, occupied $88 \%$ of the area and supported $97 \%$ of the horses'activities. Maximum herbaceous production occurred in the cheatgrass community $(841 \mathrm{~kg} / \mathrm{ha})$, and minimum herbaceous production $(151 \mathrm{~kg} / \mathrm{ha}$ ) was in the Wyoming big sagebrush/ Sandberg's bluegrass community. Levels of production in the other communities were as follows: Wyoming big sagebrush/bluebunch wheatgrass, $711 \mathrm{~kg} / \mathrm{ha}$; Wyoming big sagebrush/cheatgrass, $835 \mathrm{~kg} / \mathrm{ha}$; and low sagebrush/Sandberg's bluegrass, $155 \mathrm{~kg} / \mathrm{ha}$. Precipitation accumulations supporting the 1979 and 1980 growing seasons (Sept.-June) were 91 and $114 \%$ of the 30-year average.

\section{Population Demographics}

One-hundred-thirty-three horses were censused and identified when field work was initiated in April 1979. Of these, 42 were female, and 91 were male. Thirty-seven males and all females and their offspring were associated with bands, with a total of 21 bands. Fifty-four males roamed in small groups or as lone bachelors. One male was found dead, the result of a fall, in May of 1979. Seventeen foals were identified in 1979 during April through June, and all survived the year, increasing the population to 149 animals. Twenty-two foals were born during the spring of 1980 . Mortality during the second year totaled 3 animals. One foal was abandoned by its mother and subsequently disappeared. A second foal, observed with a broken leg, also disappeared, and a 5-year-old mare died during the winter of 1980 when her front foot became caught in a boulder pile. Total population at the close of the study in March, 1981, was 168 animals.

Annual rate of population increase, estimated from total population counts in March of each year, averaged 13\% during the study. At this rate 6 years are required for a population to slightly more than double in size. This rate of population increase, however, is probably negatively biased, relative to potential rates of increase, by the large proportion of males present on the area. The

Table 2. Number of relocations, span of months observed, minimum convex polygon, and $90 \%$ confidence ellipse estimates of home range sizes for 14 bands and 10 bachelors.

\begin{tabular}{|c|c|c|c|c|}
\hline Band & $\begin{array}{l}\text { Number of } \\
\text { relocations }\end{array}$ & $\begin{array}{c}\text { Number of } \\
\text { months } \\
\text { observed }\end{array}$ & $\begin{array}{c}\text { Area of } \\
\text { convex } \\
\text { polygon } \mathrm{km}^{2}\end{array}$ & $\begin{array}{c}\text { Area of } \\
\text { ellipse } \mathrm{km}^{2}\end{array}$ \\
\hline A & 56 & 23 & 12.0 & 17.0 \\
\hline B & 30 & 17 & 8.1 & 11.3 \\
\hline C & 24 & 20 & 6.5 & 13.3 \\
\hline D & 17 & 19 & 6.6 & 14.1 \\
\hline$\overline{\mathbf{E}}$ & 14 & 19 & 5.4 & 15.6 \\
\hline $\mathbf{F}$ & 16 & 19 & 5.4 & 13.0 \\
\hline $\mathbf{G}$ & 17 & 18 & 6.7 & 13.3 \\
\hline $\mathbf{H}$ & 23 & 22 & 12.1 & 16.0 \\
\hline $\mathbf{K}$ & 15 & 7 & 5.7 & 11.8 \\
\hline $\mathbf{K}^{\prime}$ & 10 & 15 & 18.5 & 72.8 \\
\hline $\mathrm{L}$ & 23 & 23 & 24.8 & 54.1 \\
\hline $\mathbf{N}$ & 15 & 15 & 25.2 & 60.7 \\
\hline $\mathbf{P}$ & 10 & 17 & 11.6 & 45.8 \\
\hline $\mathbf{S}$ & 14 & 14 & 16.4 & 37.0 \\
\hline $\bar{x}$ & 20.4 & 17.7 & 11.8 & 28.3 \\
\hline $\mathbf{s}$ & & & 6.9 & 21.4 \\
\hline \multicolumn{5}{|c|}{ Bachelor } \\
\hline 1 & 49 & 22 & 15.0 & 20.3 \\
\hline 2 & 47 & 21 & 18.0 & 22.0 \\
\hline 5 & 29 & 24 & 11.8 & 23.1 \\
\hline 6 & 11 & 3 & 2.6 & 8.1 \\
\hline 8 & 13 & 22 & 12.7 & 26.6 \\
\hline $10^{1}$ & 19 & 21 & 74.7 & 147.3 \\
\hline 11 & 17 & 22 & 18.1 & 38.1 \\
\hline 12 & 16 & 22 & 23.6 & 33.2 \\
\hline 26 & 14 & 20 & 6.4 & 15.0 \\
\hline 28 & 10 & 17 & 12.1 & 45.7 \\
\hline $\bar{x}$ & 22.9 & 19.1 & 12.3 & 25.8 \\
\hline s & & & 5.1 & 11.6 \\
\hline
\end{tabular}

${ }^{1}$ Data for bachelor number 10 not included in calculation of means and standard deviations. 
male-biased ( 2.2 males/female) population initially censused in 1979 was most likely a product of gathering activities 6 months prior to initiation of this project. One hundred fifty-nine males and 181 females were removed from the area at that time. When these values are combined with 91 males and 42 females left on the area, a more equitable ratio of 1.1 males/female is obtained, and a higher rate of population increase seems possible.

\section{Habitat Use}

Five-hundred-twenty-three sightings of horses were recorded on the area. Home range sizes were estimated for 14 bands and 10 bachelors (Table 2). Home range estimates for bands and bachelors averaged 11.8 and $12.3 \mathrm{~km}^{2}$, respectively, with the minimum convex polygon method. With ellipse procedures respective band and bachelor home ranges averaged 28.3 and $25.8 \mathrm{~km}^{2}$. Data for band $B$ and bachelor number 12 differed significantly $(P<0.05)$ from the bivariate normal distribution, so ellipse estimates of home range size for these animals should be accepted only with reservations. Average band and bachelor home range sizes did not differ significantly $(P>0.05)$ with either estimation method. Ratios of minimum convex polygons to the $90 \%$ confidence ellipse estimates averaged 0.50 and ranged from 0.25 to 0.81 . Because the number of relocations used to estimate home ranges were relatively small $(\bar{x}=21.3)$, we believe the ellipse procedures provided the most accurate estimate of home range size.

Only one horse, bachelor number 10 (Table 2), failed to settle in a well-defined area during the study. Respective polygon and ellipse estimates of this animal's home range were 74.7 and 147.3 $\mathrm{km}^{2}$. Because the animal's behavior and patterns of movement seemed atypical for the area, these values were not included in the calculation of means.

The horses did not appear to be severely confined by pasture boundaries, as no home range encompassed the entire area within any of the pastures. Similarly, no instances or evidences of horses breaching or jumping fences were observed. All of the observed interpasture movements of horses involved passage over natural boundaries or through open gates.

One band and 2 bachelors made permanent moves to new home ranges during the study. Band $\mathrm{K}$ (Table 2 moved from McIntyre into the Riverside pasture (band $K^{\prime}$ ) in Sept. 1979, after being observed for 7 months. Distance from the center of the original to the center of the new home range was $8.5 \mathrm{~km}$. Two bachelors, initially detected in the east-central portion of the Riverside pasture, moved permanently into the east portion of the McIntyre pasture in June, 1980. Only 8 relocations of these animals were made in each pasture, and their data were not included in the home range estimates.

Home ranges of bands and bachelors frequently overlapped and in many instances were nearly superimposed. Harem stallions defended small perimeters in the immediate vicinity of their bands, but no territorial behavior was observed. Aggregations of overlapping home ranges of bands and bachelors conformed to the "herd" concept defined by Miller (1980). Six herds occurred on the area (Fig. 1). In general, the bands and bachelors constituting each herd appeared to voluntarily remain within their respective herd areas. The shift of band K's home range from herd 4 to herd 5 was the only instance of movement detected. Although herd boundaries roughly paralleled fences and major drainages, no impassable barriers continuously impeded the movements of horses. Gates both within and on the perimeter of the area were often open for extended periods, so horses had ample opportunity to move in any direction.

Seasonal shifts of home ranges were not observed, and a selected band or individual could be easily located in any season. Yeararound sources of adequate forage and water probably contributed to the strong fidelity of these animals to their respective home ranges or herds. Rugged topography may also have restrained the movements of horses to some degree. As an indication of the rugged nature of the area, a sampling of 1,500 randomly selected points on USGS topographic maps revealed an average slope of $37 \%$.

Home range sizes were not significantly correlated $(P>0.05)$ with herbage production or number of horses per band with either of the home range estimation procedures. Herbaceous production within home ranges outlined with ellipse procedures averaged 389 $\mathrm{kg} / \mathrm{ha}$ and ranged between 153 and $711 \mathrm{~kg} / \mathrm{ha}$. The amount of each ellipse for which applicable forage production data were available averaged $95 \%$. For home ranges outlined with minimum convex polygons, herbaceous production averaged $355 \mathrm{~kg} / \mathrm{ha}$ and ranged between 150 and $733 \mathrm{~kg} / \mathrm{ha}$. The amount of each polygon for which applicable forage data were available averaged $96 \%$.

Home range size was negatively correlated $(P<0.01)$ with the density of water sources within home ranges. Little predictive power was gained, however, as respective coefficients of determination were 0.52 and 0.37 with the convex polygon and ellipse methods of home range estimation.

The hypothesis that horses utilized plant communities in proportion to their availabilities was rejected $(P<0.01)$ for herds, 1,2 ,

Table 3. The percentage of herd area, percentage of observations of horses, and relative preference ratings of each plant community occurring in each of four herd areas.

\begin{tabular}{|c|c|c|c|c|c|c|c|c|c|c|}
\hline \multirow{2}{*}{\multicolumn{2}{|c|}{ Herd }} & \multicolumn{9}{|c|}{ Community } \\
\hline & & \multicolumn{2}{|c|}{$\begin{array}{l}\text { Wyoming big Stiff sage- } \\
\text { sagebrush/ brush/ } \\
\text { bluebunch } \\
\text { wheatgrass bluegrass }\end{array}$} & $\begin{array}{l}\text { Cliff } \\
\text { rock }\end{array}$ & \multirow{2}{*}{$\begin{array}{l}\begin{array}{l}\text { Shrub } \\
\text { scabland }\end{array} \\
1 \\
0 \\
0.00^{*}\end{array}$} & \multirow[t]{2}{*}{$\begin{array}{l}\text { Bitterbrush/ } \\
\text { grass }\end{array}$} & \multirow[t]{2}{*}{$\begin{array}{l}\text { Low sage- } \\
\text { brush/ } \\
\text { Sandberg's } \\
\text { bluegrass }\end{array}$} & \multicolumn{2}{|c|}{$\begin{array}{ll}\text { Wyoming big Wyoming big } \\
\text { sagebrush/ } & \text { sagebrush/ } \\
\text { Sandberg's } & \text { Cheat- } \\
\text { bluegrass } & \text { grass }\end{array}$} & \multirow[t]{2}{*}{ Cheatgrass } \\
\hline $\mathbf{A}$ & $\begin{array}{l}\text { Herd area }(\%) \\
\text { Horses }(\%) \\
\text { Relative preference }\end{array}$ & $\begin{array}{l}85 \\
77 \\
0.91\end{array}$ & & & & & & $\begin{array}{l}14 \\
4 \\
0.29 *\end{array}$ & $\begin{array}{l}1 \\
19 \\
19.00^{*}\end{array}$ & \\
\hline B & $\begin{array}{l}\text { Herd area }(\%) \\
\text { Horses }(\%) \\
\text { Relative preference }\end{array}$ & $\begin{array}{l}38 \\
64 \\
1.68 *\end{array}$ & & & $\begin{array}{l}4 \\
0 \\
0.00\end{array}$ & & & $\begin{array}{l}17 \\
23 \\
1.35^{*}\end{array}$ & $\begin{array}{l}31 \\
9 \\
0.29 *\end{array}$ & $\begin{array}{l}10 \\
3 \\
0.30^{*}\end{array}$ \\
\hline D & $\begin{array}{l}\text { Herd area }(\%) \\
\text { Horses }(\%) \\
\text { Relative preference }\end{array}$ & $\begin{array}{l}1 \\
1.00\end{array}$ & $\begin{array}{l}1 \\
0 \\
0.00 *\end{array}$ & & $\begin{array}{l}1 \\
0 \\
0.00^{*}\end{array}$ & $\begin{array}{l}1 \\
0 \\
0.00^{*}\end{array}$ & $\begin{array}{l}29 \\
39 \\
1.35^{*}\end{array}$ & $\begin{array}{l}65 \\
57 \\
0.88\end{array}$ & $\begin{array}{l}2 \\
3 \\
1.50\end{array}$ & \\
\hline $\mathbf{E}$ & $\begin{array}{l}\text { Herd area }(\%) \\
\text { Horses }(\%) \\
\text { Relative preference }\end{array}$ & $\begin{array}{l}17 \\
7 \\
0.41 *\end{array}$ & & $\begin{array}{l}2 \\
0 \\
0.00^{*}\end{array}$ & $\begin{array}{l}11 \\
0 \\
0.00^{*}\end{array}$ & $\begin{array}{l}<1 \\
0 \\
0.00\end{array}$ & $\begin{array}{l}4 \\
2 \\
0.50\end{array}$ & $\begin{array}{l}32 \\
32 \\
1.00\end{array}$ & $\begin{array}{l}32 \\
53 \\
1.66^{*}\end{array}$ & $\begin{array}{l}3 \\
6 \\
2.00^{*}\end{array}$ \\
\hline
\end{tabular}

* Relative preference rating differs significantly from a value of $I(P<0.02)$. 


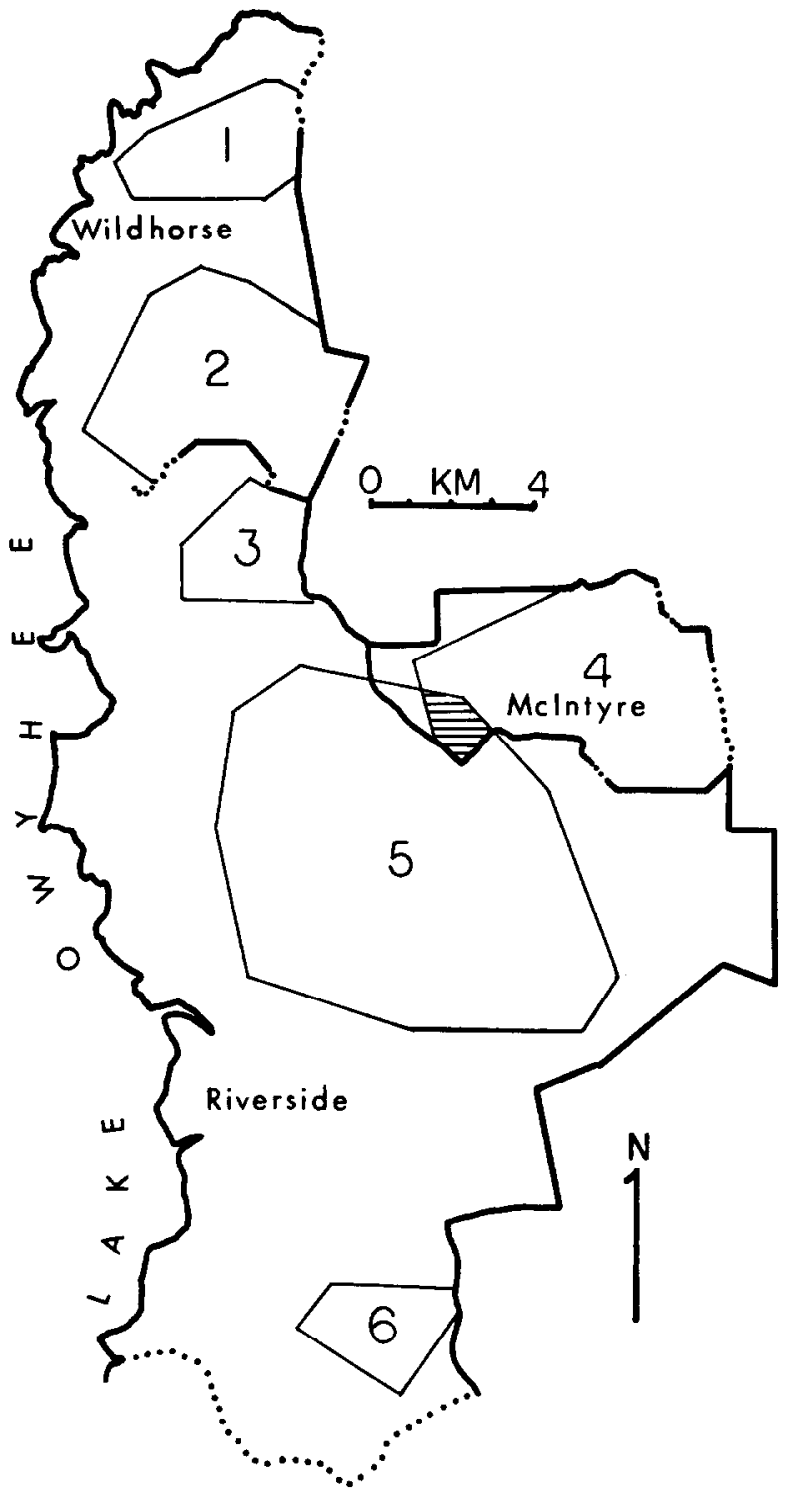

Fig. 1. Distribution of 6 herds of horses on the Owyhee study area.

4, and 5 (Table 3). Herds 3 and 6 supported small numbers of horses and were not included in this analysis. Each herd made greater than expected use $(P<0.02)$ of one community or another. Little predictive power was gained from this analysis, however, because the herds did not demonstrate a universal, positive preference for any of the plant communities common to each of the herd areas. This, combined with the information that animals in each herd were more frequently observed in the most prevalent plant community, suggested that plant community composition was not a driving force in the horses' selection of habitats.

Only the shrub scabland community appeared to be universally avoided by horses. This plant community typically occurred on steep, southern aspects and supported a diversity of shrub species from the Artemisia, Eriogonum, Chrysothamnus, and Salvia genera. Little, if any, herbaceous production was evident in these areas, and since horses typically prefer a diet of graminoids (Hansen 1976, Hanley and Hanley 1982, McInnis 1985), they would not be expected to spend much time foraging in this community.

These data were gathered throughout a 2-year period, and are indicative of the year-around patterns of use by the horses. We recognize that within home ranges or herd areas, horses may demonstrate seasonal preferences for one community or another (Nelson 1978, Salter and Hudson 1979). Our sample sizes, however, were too small to address such hypothesis with any statistical confidence. Nevertheless, our observations were distributed evenly throughout the year, and we believe the data are indicative of the plant communities making the greatest contribution to the support of the respective herds over the entire year. The horses did not appear to exhibit seasonal differences in habitat preferences.

Several sources and our own observations indicate feral horses prefer to occupy ridgetops or elevated terrain (Pellegrini 1971, Welsh 1975, Keiper and Berger 1982). This aspect of their behavior was not considered in our evaluations of the horses'preferences for plant communities and may have confounded our interpretation of these data to some degree. Keiper and Berger (1982) speculated horses sought ridgetops to minimize harassment by insects. The horses on our study area preferred ridgetops on a year-around basis, even during fall and winter months when insects were notably absent. We speculate these horses sought elevated terrain as a means of enhancing their view of the surrounding area and negating potential threats to their safety.

The hypothesis that horses watered at random periods throughout the day was rejected $(P<0.01)$. Horses preferred to drink during the first and last periods of daylight. Forty-six percent of the daylight watering events occurred during the first period of the day, and $33 \%$ occurred during the last period. The remaining $21 \%$ of the observations were dispersed throughout the balance of the day. Watering events averaged 16.1 minutes in duration, with a range of 1 to 45 minutes. Typically groups of horses moved rapidly to and from water with very few feeding or loafing activities occurring in the immediate vicinity of the drinking areas.

Water sources were plentiful and generally well dispersed about the area when compared to other ranges supporting horses in the western United States (Berger 1977, Miller 1980). Nearly 100\% of the Wildhorse and McIntyre pastures were within $1.6 \mathrm{~km}$ of perennial water, while only $64 \%$ of the Riverside pasture occurred within this distance of a perennial source. In the Riverside pasture a trend surfaced during both years showing a slight concentration of horses near permanent water in the warm, dry summer months when sightings of horses averaged $1.56 \mathrm{~km}$ from water, and some dispersal of the animals as seasons progressed through fall (1.91 $\mathrm{km})$ and winter $(2.02 \mathrm{~km})$ into spring (2.16) when temporary sources were most abundant. Mean distances of sightings of horses from water were not significantly different among seasons, however.

\section{Literature Cited}

Baltazor, H.E., and J. Baltazor. 1976. The last of the mustangers and jerkline skinners. Schwartz Printing Co., Nampa, Idaho.

Berger, J. 1977. Organizational systems and dominance in feral horses in the Grand Canyon. Behav. Ecol. Sociobiol. 2:131-146.

Burt, W.H. 1943. Territoriality and home range concepts as applied to mammals. J. Mammal. 24:346-352.

Feist, J.D. 1971. Behavior of feral horses in the Pryor Mountain Wild Horse Range. M.S. Thesis, Univ. Michigan, Ann Arbor.

Hanley, T.A., and K.A. Hanley. 1982. Food resource partitioning by sympatric ungulates on Great Basin rangeland. J. Range Manage. 35:152-158.

Hansen, R.M. 1976. Foods of free-roaming horses in southern New Mexico. J. Range Manage. 29:347.

Hansen, R.M., R.C. Clark, and W. Iawhorn. 1977. Foods of wild horses, deer, and cattle in the Douglas Mountain area, Colorado. J. Range Manage. 30:116-118.

Harrison, J.L. 1958. Range of movement of some Malayan rats. J. Mammal. 39:190-206.

Jennrich, R.I., and F.B. Turner. 1969. Measurement of noncircular home range. J. Theoret. Biol. 22:227-237.

Keiper, R.R., and J. Berger. 1982. Refuge-seeking and pest avoidance by feral horses in desert and island environments. Applied Animal Ethology. 9:111-120.

Koeppl, J.W., N.A. Slade, and R.S. Hoffman. 1975. A bivariate home range model with possible application to ethological data analysis. $J$. Mammal. 56:81-90. 
Krueger, W.C. 1972. Evaluating animal forage preference. J. Range Manage. 25:471-475.

Marcum, C.L., and D.O. Loftsgaarden. 1980. A nonmapping technique for studying habitat preferences. J. Wildl. Manage. 44:963-968.

McInnis, M.L. 1985. Ecological relationships among feral horses, cattle, and pronghorn in southeastern Oregon. Ph.D. Thesis, Oregon State Univ., Corvallis.

Miller, R. 1980. The ecology of feral horses in Wyoming's Red Desert. Ph.D. Thesis, Univ. Wyoming, Laramie.

Miller, R. 1983a. Habitat use of feral horses and cattle In Wyoming's Red Desert. J. Range Manage. 36:195-199.

Miller, R. 1983b. Seasonal movement and home ranges of feral horse bands in Wyoming's Red Desert. J. Range Manage. 36:199-201.

Miller, R., and R.H. Denniston, II. 1979. Interband dominance in feral horses. Z. Tierpoychol. 51:41-47.

Nelson, K.J. 1978. On the question of male-limited population growth in feral horses (Equus caballus). M.S. Thesis, New Mexico State Univ., Las Cruces.

Pechanec, J.F., and G.D. Pickford. 1937. A weight estimate method for the determination of range or pasture production. J. Amer. Soc. Agron. 29:894-904.

Pelligrini,S.W.1971. Home range, territoriality and movement patterns of wild horses in the Wassuk Range of western Nevada. M.S. Thesis, Univ. Nevada, Reno.
Salter, R.E. 1978. Ecology of feral horses in western Alberta. M.S. Thesis, Univ. Alberta, Edmonton.

Salter, R.E., and R.J. Hudson. 1979. Feeding ecology of feral horses in western Alberta. J. Range Manage. 32:221-225.

Schoener, T.W. 1981. An empirically based estimate of home range. Theor. Pop. Biol. 20:281-325.

Smith, W.P. 1983. A bivariate normal test for elliptical home range models: biological implications and recommendations. J. Wildl. Manage. 47:613-619.

Southwood, T.R.E. 1966. Ecological methods with particular reference to the study of insect populations. Methuen \& Co., London.

Stein, C. 1945. A two sample test for a linear hypothesis whose power is independent of the variance. Ann. Math. Stat. 16:243-258.

Storrar, J.A., R.J. Hudson, and R.E. Salter. 1977. Habitat use behavior of feral horses and spatial relationships with moose in central British Columbia. Syesis. 10:39-4.

Welsh, D.A. 1975. Population, behavioral and grazing ecology of the horses of Sable Island, Nova Scotia. Ph.D. Thesis, Dalhousie Univ.

Zarn, M., T. Heeler, and K. Collins. 1977. Wild free roaming horses-status of present knowledge. U.S. Dept. Interior, Bureau of Land Management; U.S. Dept. Agr., U.S. Forest Service. DSC Federal Center Building 50, Denver, Colorado. Tech Note 294. 